\title{
埋込電極をもった増幅型撮像素子の提案
}

\author{
正会員 白 木 広 光 $^{\dagger}$
}

\section{Amplifing Image Sensor with Buried Electrode}

\author{
Hiromitsu Shiraki $^{\dagger}$
}

\begin{abstract}
The proposed structure allows opaque driving electrode to be removed from the cell surface, increasing high quantum efficiency and resulting in higher photo-sensitivity. Mode selection (such as reset, charge storage and readout) can be performed by driving electrodes buried in silicon substrate. Readout signal amplitude, which is the output of a source follower, is determined by the number of signal holes stored in each photodiode. Simulation of a device with $1000 \times 1000$ of these cells $/ \mathrm{cm}^{2}$ indicated that the sensor could be operated without image lag, blooming and low smear. The simulated photo-sensitivty, cell charge capacity and charge-to-voltage coversion factor were high enough for videocameras.
\end{abstract}

\section{1. ま え がき}

インタライン方式 CCD(Charge Coupled Device) 撮像素子の実用化が進んでいる．この方式は多くの長 所を持っているが, セル構造が複雑であるため, 超高 密度化するのが困難である. セル中に占める光電変換 領域の割合が低いため, 光電変換効率が低いなどの問 題もある。これらの点を解決するため, MOST ${ }^{1) ~ 2) ~}$ や $\mathrm{J}-\mathrm{FET}^{3) \sim 4)}$ などを用いた増幅型の撮像素子が提案 され，かなり高密度・高解像度のものが作られている. しかし, これらの素子もセルの受光面上に光吸収の大 きい駆動電極が存在するため, 光電変換効率は必ずし も高くない.

本報告では, リセット・蓄積・読出しなどのモード 制御用の電極を半導体基板中に埋め込むことによって
前記の問題点を解決できる, 接合電界効果トランジス 夕(J-FET)の原理を用いた撮像素子(増幅型)を提案 する。そして, 計算によって動作および特性を解析し た結果および, 今後の課題について述べる.

\section{2. 新しい撮像素子の提案}

ここでは, 提案する素子と現状の素子の違いを明ら かにするため, 最初に現状の素子について簡単に説明 する. 図 1 は増幅型撮像素子の中では最も進歩してい ると考えられる J-FET 型撮像素子4) のセルの深さ方 向の構造と, 信号蓄積および信号読出し時における電 子に対する静電電位を示す。

駆動電極はセルの受光面上にあって 1 水平ラインを 駆動している。また，基板は各水平ラインに共通であ る.信号蓄積時において, $X_{A}$ から $X_{C}$ までの間で発

キーワード : 増幅型撮像素子, 高感度化, 埋込電極, 動作解析, シミュレーション

1993 年 6 月 29 日受付, 1993 年 10 月 8 日再受付

† 日本電気株式会社 研究開発グループ(テ 229 相模原市下九沢 1120 , TEL 0427-79-9956)

$\dagger$ Research and Development Group, NEC Corporation (1120, Shimokusawa, Sagamihara-shi, Kanagawa 229, Japan) 


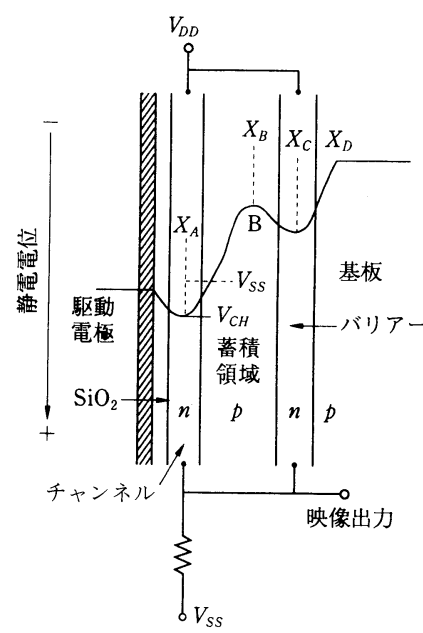

図 1 受光面上に駆動電極をもつ J-FET 型撮像素子 $\mathrm{J}$-FET type conventional image sensor.
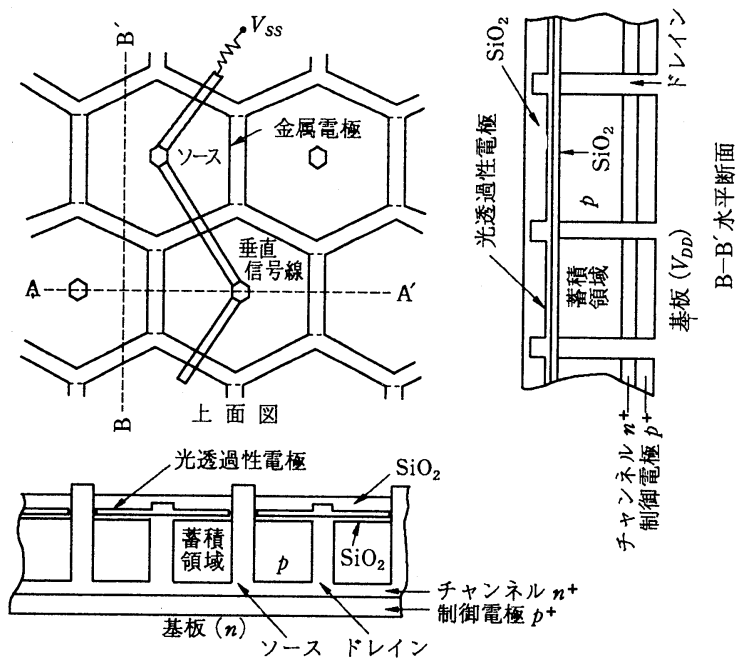

$A-A^{\prime}$ 水平断面

図 2 素子構成

Proposed device structure including $2 \times 2$ cells.

図 2 からわかるように, 各セルには受光表面から基 板へ向かって薄い光透過性の電極(例えばポリシリコ ン), $\mathrm{SiO}_{2}$ 絶緑膜, 蓄積領域 $(p)$, チャンネル $(n)$, 制 御電極 $\left(p^{+}\right)$が配置されている。またチャンネルの両 端には、ソースおよびドレインが設けられている。さ らに, ドレイン上の光透過性電極には伝搬遅延を無視 できるような金属電極がハニカム状に形成されてい る. また, セルの受光領域には, これから光透過性電 極が受光領域へ向けて拡がっている，そして，八ニカ 厶状電極には直流電圧が与えられ, 制御電極には現状 素子における駆動パルスと類似の働きをするパルスが 与えられる。

この構造では, セルのモードを変化させた時, 光透 過性電極は八ニカム電極から 1 セルだけを充放電すれ ばよいから, モード変化によるセル内の電荷の充放電 に迅速に対応できる。

なお, 制御電極の不純物濃度と駆動パルスの遅延の 関係については 7.1 節で検討する。また, 光透過性電 極の厚さについても 7.1 節で検討するが，駆動すべき 容量はセル 1 個だけであり, 駆動線の抵抗はセル上の 抵抗だけであるから，その厚さは従来の駆動電極の厚 さを水平方向の素子数の 2 乗で除した程度に減少でき る.したがって, この電極による光吸収はほとんど無 視できる.

図 2 において,ソースは蓄積領域を貫通して垂直信 号線と結ばれ，垂直信号線は大きな抵抗を介して $V_{s s}$ に達している，また，ドレインは水平方向には制御電 
極で止まっているが，垂直方向にはこれを貫通して基 板 $\left(V_{D D}\right.$ が与えられている)に達している．したがっ て, 水平方向に配列されたセル群は固有の制御電極を 持つので, 他の水平ラインとは独立に駆動モードを設 定することができる.また, 図 2 の構成からわかるよ うに，各セルは垂直信号線を介してソースフォロアを 構成している。

\section{3. 撮像素子の動作}

本論文の主目的は, 制御電極を駆動することによっ て, いかにしてソースフォロアから高感度で映像信号 を読出すかを示すことである．そこで，ここではリセ ット・蓄積・信号読出しなどの動作を説明する，なお， 動作の解析は主としてセルの深さ方向にポアソンの方 程式を解くことによって行った。図 3(a) は解析に用 いたセルの上面を, 図 3 (b) は受光部の断面を示して いる. 光電変換領域の厚さは近赤線領域においても高 い光電変換効率が得られるように $2.3 \mu \mathrm{m}$ とかなり厚 くし, 広いダイナミックレンジが得られるように濃度 $N_{A}$ は $3.0 \times 10^{15} / \mathrm{cm}^{3}$ と高くした。また，チャンネル 領域の幅と濃度は, 蓄積領域に最大の信号正孔が蓄積

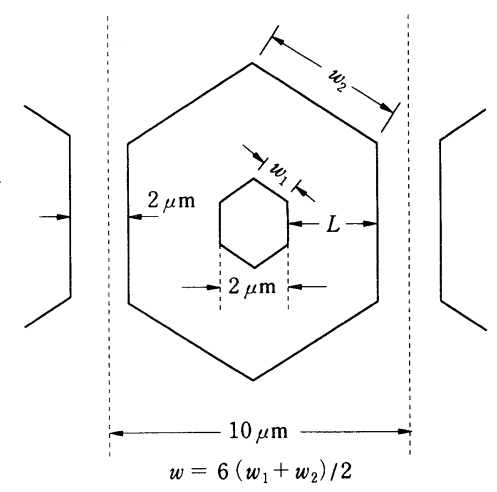

(a) 上面図

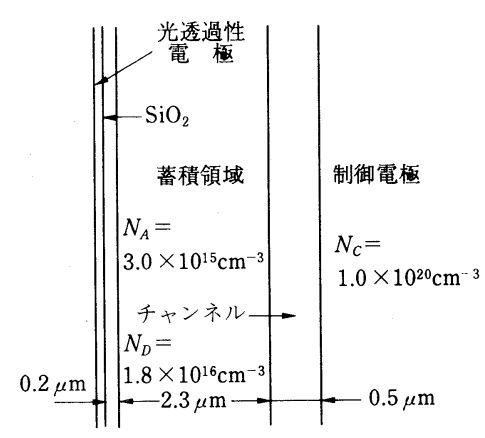

(b) 断面図

図 3 特性解析用のセル構造

Cell Structure for performance simulation.
されたとき, 約 $1 \mathrm{~V}$ の信号出力が得られるように設 定した.チャンネルの幅は $0.5 \mu \mathrm{m}$ であり, その濃度 $N_{D}$ は $1.8 \times 10^{16} / \mathrm{cm}^{3}$ である.

\section{1 リセット動作}

これは制御電極に負電圧を印加して, 蓄積領域に存 在する正孔を制御電極に引き込む動作である。いま，


また,ソースおよびドレイン電位は共に $0 \mathrm{~V} と し$, 蓄積領域は浮遊しているとする. 図 4 は制御電極の電 位をパラメータとして, セルの深さ方向の電位分布を 示す. 図 4 より制御電極の電位 $V_{C}$ を負方向に大きく すると, 制御電極から延びる空乏層は, まずチャンネ ル中を拡がり，蓄積領域に達することがわかる．この 時の制御電極の電位を $V_{S T}$ で表す。さらに制御電極 の電位を低くすると, 空乏層は $\mathrm{SiO}_{2}$ 絶縁膜と蓄積領 域の界面からチャンネルに向かって拡がり, やがてチ ヤンネルに達する．この時の制御電極の電位は $V_{J U S T}$ で示されている.図 4 には, 制御電極に $V_{J U S T}$ より大 きな負電位を与えた時の電位分布(オーバーリセット 時)も示されている.このように, 蓄積領域は完全に 空乏化できるので残像は発生しない.

なお図 4 より,リセットに必要な電圧は約 $20 \mathrm{~V}$ と かなり高くなっているが，これを低下する手段につい ては 7.1 節で検討する。

\section{2 蓄積動作}

これは空乏化した蓄積領域に映像信号としての正孔 を蓄積する動作である．図 5 は蓄積領域に深さ方向に 幅 $\alpha$ だけ信号正孔が存在する時のセルの深さ方向の 電位分布を示す。この時, 制御電極の電位は $\left(V_{S T}\right.$ $-4.2 \mathrm{~V})$ に設定してある. 図より蓄積できる最大の $\alpha$

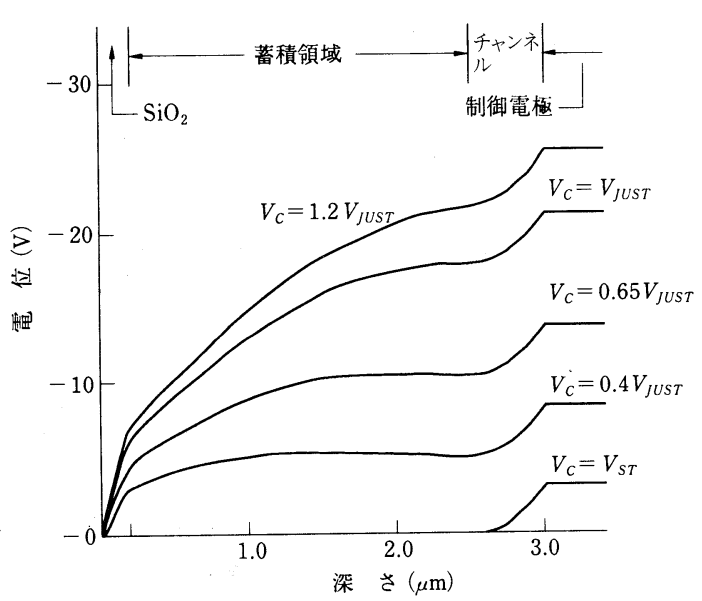

図 4 リセット時の電位分布

Potential profile at reset. 


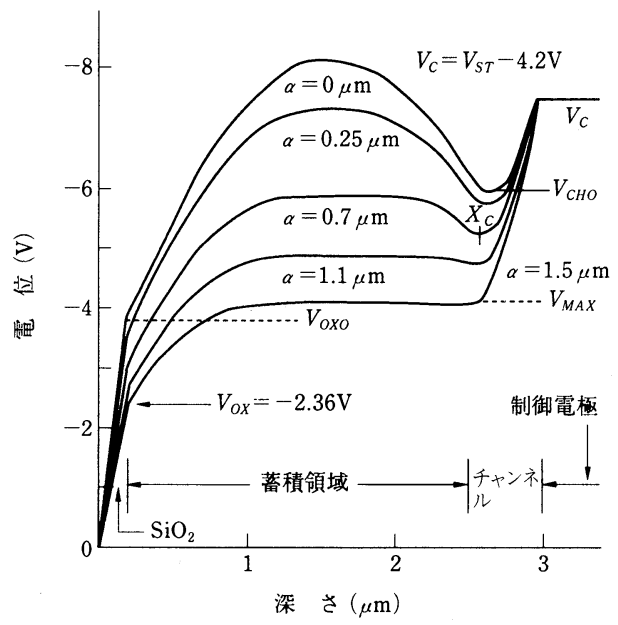

図 5 信号蓄積時の電位分布

Potential profile at signal storage.

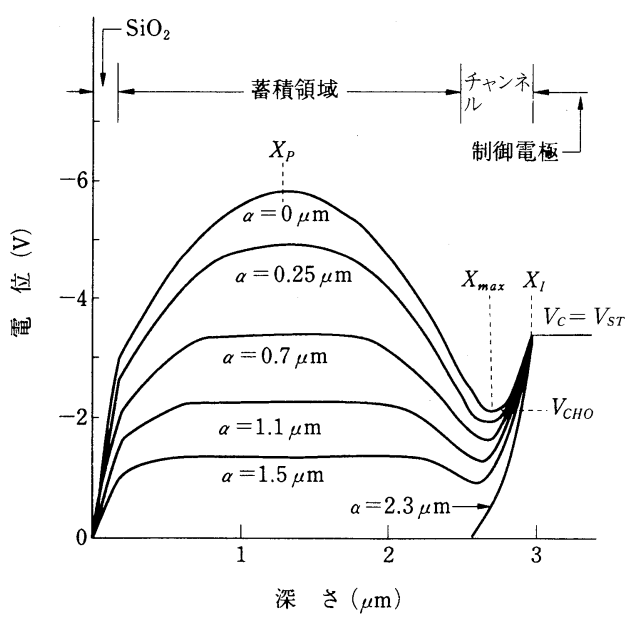

図 6 信号読出し時の電位分布 Potential profile at signal readout.

は $1.5 \times 10^{-4} \mu \mathrm{m}$ (蓄積領域の幅の約 $65 \%$ )で，それ以 上正孔が存在しても制御電極に流れ込んでしまうた め, ブルーミングは発生しないことがわかる。なお， 図 5 において $V_{O X}$ は最大の $\alpha$ に対する界面電位を示 す。信号正孔が蓄積される時, 光によって発生した電 子は $\mathrm{SiO}_{2}$ と蓄積領域の界面およびチャンネル領域に 引き寄せられる。このときソース電位 $V_{s s}$ が $\left(V_{S S}<\right.$ $\left.V_{D D}\right) V_{O X}$ より大きく設定されていれば，これらの電 子は $V_{S S}$ か $V_{D D}$ に吸収される。したがって, 蓄積時 に蓄積領域に存在するキャりヤは正孔だけである。

\section{3 信号読出し動作}

これは蓄積領域に存在する信号正孔数によって変調

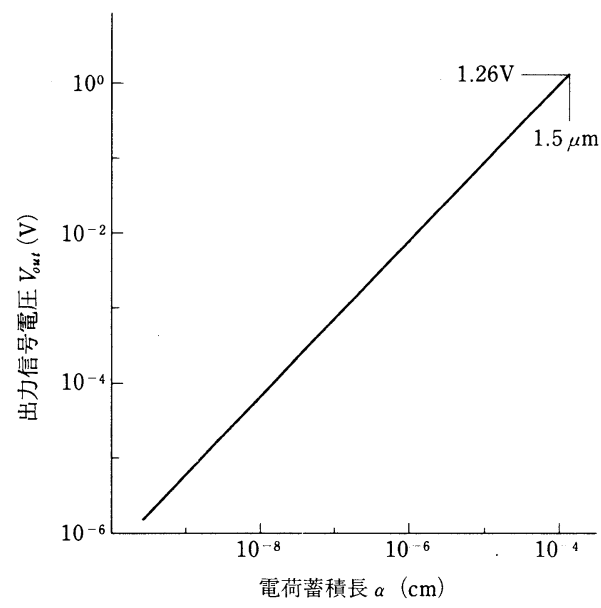

図 7 信号電荷蓄積長と信号電圧の関係

Relation between output voltage and charge storage length $(\alpha)$.

されるチャンネル電位を, ソースフォロアの出力とし て読出す動作である．この時, 蓄積領域に存在する信 号正孔数としては，3.2 節で考えた量がそのまま保持 されている. 図 6 は制御電極の電位を $V_{S T}$ とした時 の深さ方向の電位分布を $\alpha$ をパラメータとして示し ている. $\alpha$ の増加と共にチャンネル電位は増加し, 蓄 積領域が正孔で満たされると, チャンネル電位は $0 \mathrm{~V}$ になることがわかる．図 6 の場合，すべての $\alpha$ に対 してチャンネル電位は界面電位より大きくなるように 設計してある。また，図 5 において， $\alpha$ の最大值は $1.5 \mu \mathrm{m}$ であったから, 読出し時にはチャンネル電位 はこの值まで読めればよい.しかし, 図6では, 読出 し期間中に強い光が入射することも考慮して， $\alpha=2.3$ $\mu \mathrm{m}$ (蓄積領域の幅) までチャンネル電位を読めるよう に $V_{C}$ を $V_{S T}$ に設定した。

次に, 図 5 , 図 6 に示したような特性のセル 1 個を 用いて，ソースフォロアによって映像信号を得ること を考える。いまソース電位として， $V_{O X}$ と図 6 に示し た $\alpha=0 \mu \mathrm{m}$ の時のチャンネル電位 $V_{\text {Сно }}\left(V_{\text {OX }}<V_{\text {Сно }}\right)$ の間の電位を与え, ドレイン電位を $0 \mathrm{~V}$ とす。 セ ルが蓄積状態にあれば，ソース電位は図 5 の界面の電 位や, チャンネルの最大電位よりも高いので, ソー ス・ドレイン間に電流は流れず, ソースフォロアの出 力電圧は $V_{s s}$ になる。一方，七ルが読出し状態にあれ ば，電流はチャンネルを通り，次に大きな抵抗を通り

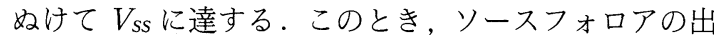
力はチャンネルの最大電位点に対応した擬フェルミレ ベルとして得られる。したがって, 図 6 からわかるよ うに, $\alpha$ 值の増加と共にソースフォロアの出力は増加 
する. したがって, 出力信号 $V_{\text {ouT }}$ は $\alpha=0$ の時のチ ヤンネル電位 $V_{\text {Сно }}$ 基準としたチャンネル電位の増 加分として得ることができる.

図7は，図6に示されている $\alpha$ 值とチャンネル電 位の関係を, $\alpha$ 值と出力信号の関係に書き改めたもの である. 図 7 より， $\alpha$ と出力信号は良い直線性を保っ ていることがわかる.

\section{4. 光電变換特性}

本論文で提案したセル構造では, 受光面上の電極に よる光吸収はほとんどない。また，図 1 で説明したよ うな界面方向に移動する正孔による光電変換損失は生 じない.したがって, 高い光電変換効率が期待でき る。

本節では，まず図 5 の蓄積時の電位分布に基づい て, 入射光量と $\alpha$ の関係を計算する. 光がセル表面 から入射した時, $\mathrm{SiO}_{2}$ と蓄積領域の境界からチャン ネル中の最大電位の点 $X_{C}$ の間で発生した正孔は蓄積 領域に蓄えられる。セル当たり， 1 蓄積期間 $\left(T_{S}=\right.$ $1 / 60 \mathrm{sec}$ ) 当たりの蓄積量 (信号正孔数)を $N_{S H}$ とす る. $N_{S H}$ を, 蓄積期間中に $X_{C}$ が変化することを考慮 して， $T_{S}$ を 10 等分し，各時間間隔ごとに波長に関す る積分を行って算出した. 図 8 には, この結果得られ た素子表面での入射光強度と, 次の式によって算出し た $\alpha$ の值の関係が示されている.

$$
\alpha=\frac{N_{S H}}{N_{A} \cdot L \cdot W}
$$

また，図中には $N_{S H}$ の值も示されている。（1)式 において， $L, W$ はそれぞれ図 3 に示したセルのチ

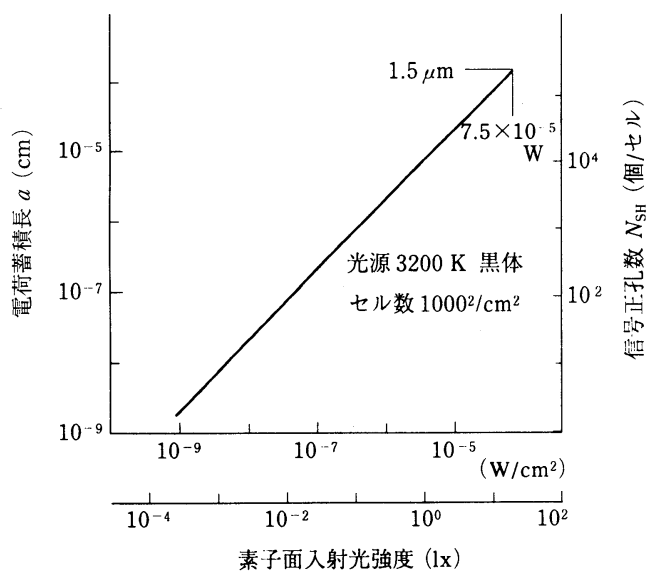

図 8 撮像面照度と信号正孔数および電荷蓄積長の関係 Relation between device illumination and number of singnal hole $\left(N_{S H}\right)$ or charge storage length $(\alpha)$.
ヤンネル長およびチャンネル幅である．この計算にお いては, ソースおよびドレイン部以外は光電変換に対 して有効であると仮定した. 有効領域はセル面積の $52 \%$ であ.また，光透過性電極による光吸収や反射 はないと仮定した。

図 8 から， $\alpha$ 值は入射光強度にほぼ比例して増加し ていることがわかる.

したがって, 図 7 と図 8 を結びつけると, 入射光量 に対して出力信号 VOUT が求まり, これらは良い比例 関係にあるといえる。

なお，上に述べた計算方法において，入射光量とし て光量子数を与え, 波長に関する積分を省略すれば, 量子効率を求めることができる. 図 9 に $\alpha$ が $1.5 \mu \mathrm{m}$ に達した時点での量子効率を示した. 図 9 より, 短波 長の光に対しても高い量子効率が期待できることがわ かる. しかし, 従来素子4) における駆動電極の厚さ や，そのセル表面への被覆率が明らかでないので, 改 善の程度を示すことは困難である.

ここで提案したセルについて, これまでの解析から わかった主要な事柄をとりあえずまとめておく.

まず，セル当たりの最大信号正孔数は図 5 の $\alpha=$ $1.5 \mu \mathrm{m}$ に対応し, 図 8 から $N_{S H}=2.2 \times 10^{5}$ hole $/$ cell となる.したがって, 光電変換感度は $2.9 \times 10^{9}$ hole $\cdot \mathrm{cm}^{2} / \mathrm{W} \cdot$ cell となる。 また, 信号正孔と信号電圧 の間の変換係数 $S$ は

$$
S=\frac{V_{o U T}}{N_{S H}}
$$

で与えられ， $\alpha=1.5 \mu \mathrm{m}$ に対する $V_{\text {ovt }}$ は, 図 7 から $1.26 \mathrm{~V}$ であるので, $S=5.7 \mu \mathrm{V} /$ hole となる.

従来, 素子4) において, $S$ の值は $15.4 \mu \mathrm{V} /$ hole と 報告されているが，これは増幅後の值であり，比較は できない，なお，セルの大きさを変えても，セルを表

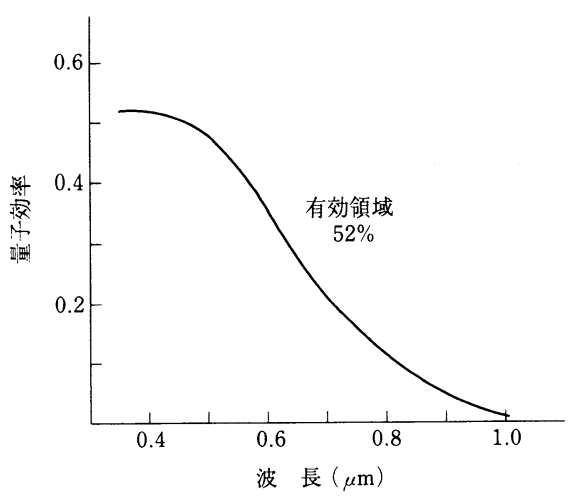

図 9 量子効率 Quantum efficiency. 
面から見た場合の各部の比率を一定に保ち, 不純物プ ロファイルを変えなければ図 7 の関係は不変であり, 図 8 の入射光強度と $\alpha$ の関係も不変である. しかし, 図 8 の右側軸の信号正孔数は $(L \times W)$ に比例するの で，セルサイズと共に減少する。したがって，セルサ イズを小さくすると変換係数 $S$ は増加する.

最大蓄積正孔数は, 従来素子 ${ }^{4)}$ の值の $6.5 \times 10^{4}$ に比 べて約 3.4 倍であり, $S$ の值も従来素子の増幅後の值 と比べてもそれほど小さくはない.したがって，これ らの值自体は充分大きな值であると考えられる。これ らの值が有効に生かせるか否かは，雑音の大きさにか かっている.

\section{5. セルの設計値と光電変換特性}

本節では, セルの設計値を変えた場合の光電変換特 性について検討する，設計值を変更する場合, 酸化膜 厚と制御電極の濃度は一定とした。その理由は, 次の 通りである。

まず，酸化膜を厚くするとりセット電圧が高くなる ため駆動上不利である。また，薄くすると図 5 の $V_{O X}$ が大きく(負で絶対值小)なるため小さな信号電圧しか 得られないからである。また, 制御電極の濃度は駆動
パルスの遅延を小さくするため非常に高い濃度が必要 であり，非常に高い濃度で多少值を変えてもほとんど 特性変化がないからである.

図 10 の (a)，（b)，（c），(d)に, 図 3 の設定值 から蓄積領域濃度, チャンネル幅, チャンネル濃度, 蓄積領域幅だけを変化させた場合の, 信号電圧 $\left(V_{\text {out }}\right)$ と (2) 式から求めた変換係数 $(S)$ が示されている. 図 10 の $(\mathrm{a}) \sim(\mathrm{c})$ においては, 蓄積時の制御電極の電 位は $\alpha=1.2 \mu \mathrm{m}$ において, ちょうどオーバーフロー が起こるように設定し, 図 $10(\mathrm{~d})$ においては蓄積領 域幅の $52 \%$ の $\alpha$ 值に対して，ちょうどオーバーフロ 一するように設定した。また，読出し時の制御電極の 電位は $V_{S T}$ とした。このように設定すると, 図 10 の いずれの条件においても前述の $V_{O X}<V_{C H O}$ という条 件が満たされ, セルは正常に動作する.

さて, 図 10 の ( a ) 〜 ( c ) 加蓄積領域濃度, チャ ンネル幅, チャンネル濃度の増加と共に信号電圧が増 加することがわかる．この理由は，これらの值が大き いほど $\alpha=0 \mu \mathrm{m}$ に対するチャンネル電位が負で大き くなり, $\alpha=1.2 \mu \mathrm{m}$ までのチャンネル電位の変化量が 大きくなるためである。また, 図 $10(\mathrm{~d})$ )場合には, 蓄積領域幅が増すほど信号電圧が増加しているが, こ

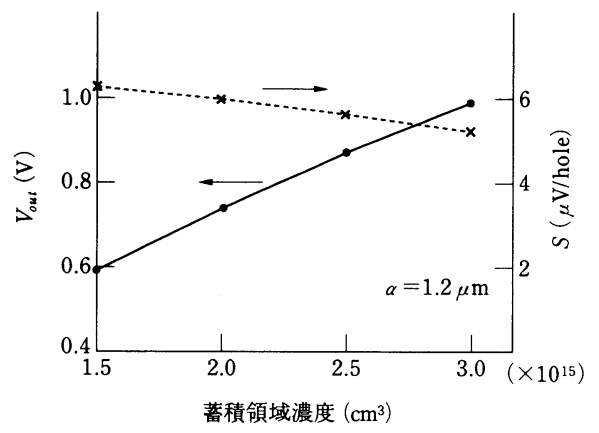

(a)

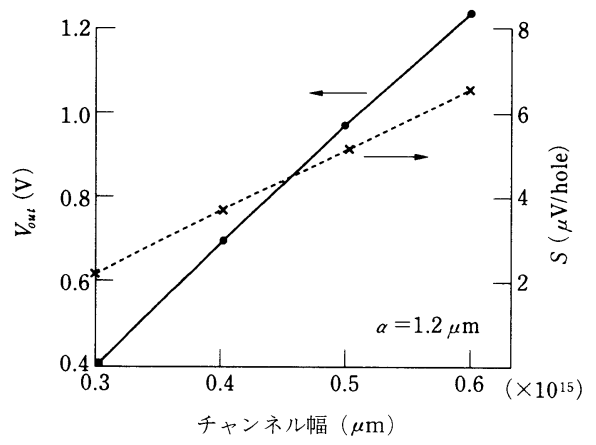

(b)

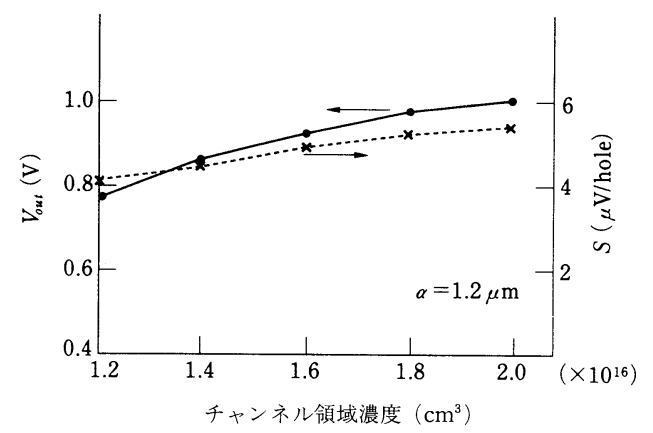

(c)

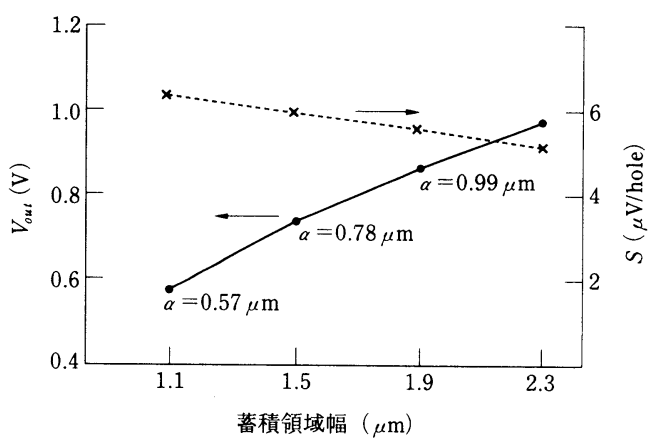

(d)

図 10 セルデザインと出力特性の関係

Relations between cell design and output characteristics. 
の理由も図 $10(\mathrm{a}) \sim(\mathrm{c})$ )場合と同じである.

また図 10 より, 変換係数 $S$ を向上させるために は, 一般的に蓄積領域濃度を低くし，チャンネル幅と その濃度を増し, 蓄積領域の幅を狭くすればよいこと がわかる。

\section{6. 雑音およびスミア}

雑音にはランダム雑音と固定パターン雑音がある.

\section{1 ランダム雑音}

ランダム雑音には, 通常の接合ゲート型トランジス 夕においても発生する熱雑音と $1 / f$ 雑音があり ${ }^{5)}$, 撮 像素子特有の雑音として暗電流によるショット雑音が ある.ここでは暗時の雑音だけを求める.

熱雑音 $v_{t h}$ は

$$
v_{t h} \simeq\left(4 k T \frac{1}{g_{m}} \Delta f\right)^{1 / 2}
$$

のように表される6).（3)式において， $k$ はボルツマ ンの定数, $T$ は動作温度 $(300 \mathrm{~K}), g_{m}$ は図 6 の $\alpha=0$ $\mu \mathrm{m}$ に対応するトランスコングクタンス, $\Delta f$ は信号 読出しの帯域である.

$g_{m}$ は, 図 6 の $\alpha=0 \mu \mathrm{m}$ の状態を考え, ソース電位 を $V_{C H O}$ に固定して, $x_{p}$ の電位を $+0.1 \mathrm{~V}$ 変化させた 時に, ドレイン側ピンチオフの状態で流れるソース・ ドレイン電流から求めた. $g_{m}$ の值は, $1.0 \times 10^{-3}$ シー メンスであった。

また, 帯域 $\Delta f$ は次のようにして求めた。蓄積期間 (1/60 sec とする)を $T_{S}$, セル数 $N$ を $1000^{2}$, とする と水平走査時間 $T_{H}$ は

$$
T_{H} \simeq \frac{T_{S}}{\sqrt{N}}
$$

となる. 水平ブランキング期間を水平走査時間の $1 /$ 10 とし, さらにその $1 / 2$ の期間で水平ライン信号を 読出すとすると, 読出し時の帯域 $\Delta f$ は

$$
\Delta f=0 \sim \frac{20}{T_{H}}
$$

となる， $v_{t h}$ は， $4.36 \times 10^{-6} \mathrm{~V}$ となった。

$1 / f$ 雑音 $v_{1 / f}$ は次のようにして計算した 図 6 の $X_{p}$ から $X_{\max }$ の間に存在するトラッピングセ ンタの充放電により, その間の容量に印加される電圧 のゆらぎを計算する。同様にして， $X_{\max }$ から $X_{I}$ (制 御電極中の空乏層が始まる位置)までの容量に印加さ れる電圧のゆらぎを計算する。次に, これらの電圧の ゆらぎによって引き起こされるチャンネル電位のゆら ぎをそれぞれ計算する，さらに，これらのチャンネル 電位のゆらぎの 2 乗の和の平方根を求め, $1 / f$ 雑音と した。ここでは紙面の制約があるので計算の詳細は省
略し，使用した仮定と結果だけを示す

トラッピングセンタが禁止帯の中心にあり, その密 度を $1 \times 10^{9} / \mathrm{cm}^{3}$, 捕獲断面積を $10^{-15} \mathrm{~cm}^{2}$, 充放電を 考える帯域は信号読出し時の帯域とした。 $v_{1 / f}$ は 7.24 $\times 10^{-7} \mathrm{~V}$ となった

なお，上記の仮定を用いた時，トラップを介して発 生する暗電流は $0.256 \mathrm{nA} / \mathrm{cm}^{2}$ となった。この值は, 最近のシリコンデバイスでは通常得られる值である. したがって，用いた仮定は妥当なものと考えられる.

ショット雑音は次のようにして計算した。図 5 の $\mathrm{Si}-\mathrm{SiO}_{2}$ 界面が空乏化したとき, $1 \mathrm{nA} / \mathrm{cm}^{2}$ の暗電流 が発生するとし， 1 蓄積期間にセル当たりに発生する 正孔数を求めた。この正孔は，図 6 の $X_{P}$ に集まる. 次に, この正孔数のゆらぎに対応した $\alpha$ 值を計算し, これをチャンネル電位の変化分に換算してショット雑 音とした。 $v_{\text {SHOT }}$ は $3.26 \times 10^{-5} \mathrm{~V}$ となった。

以上の結果から, 最大の雑音はショット雑音である ことがわかった。ショット雑音を減少させるために は, 蓄積期間中に暗電流が発生しても，これをソース に引き込んでしまうようなセル構造や駆動法4)を考え ることが必要だろう。

これらのランダム雑音の合計は $3.29 \times 10^{-5} \mathrm{~V}$ とな り, 図 7 より最大信号出力は $1.26 \mathrm{~V}$ であるので, ラ ンダム雑音のみによるダイナミックレンジ $D$ は次式 より求まる。

$$
D=20 \log \left(\frac{1.26}{3.29 \times 10^{-5}}\right)
$$

$D$ は $91.7 \mathrm{~dB}$ となる.

なお, 以上の雑音の他にも $\mathrm{Si}-\mathrm{SiO}_{2}$ 界面の充放電に よる雑音も考えられるが，まだ定式化ができていな い.

\section{2 固定パターン雑音}

固定パターン雑音は, セルの各部の大きさや, 不純 物濃度の不均一性によるチャンネル電位の変動によっ て発生する。図 3 の構造を考えた時, $\mathrm{SiO}_{2}$ 膜の厚さ は均一性良く作れるし, 制御電極の濃度は非常に高い 場合には，その濃度が多少変化してもほとんど特性に 影響しない。したがってここでは，5節と同じ項目に 着目して固定パターン雑音を評価する。

蓄積領域やチャンネル領域をイオン注入で形成する とすると, その不均一性は 6〜8インチウェハの面内 で $0.5 \%$ 以下にできるといわれている.チップサイズ を $1 \mathrm{~cm}^{2}$ とすると不均一性は減少するが，ここでは $0.5 \%$ とて評価する。蓄積領域の幅やチャンネル幅 の不均一性については, チャンネル幅が蓄積領域の方 向に $\pm 0.5 \%$ 変動するとして評価した 
表 1 固定パターン雑音

Fixed pattern noise.

\begin{tabular}{c|c}
\hline \hline 変動項目 & 固定パターン雑音 $(\mathrm{V})$ \\
\hline 蓄積領域濃度 $+0.5 \%$ & -0.0081 \\
\hline チャンネル濃度 $+0.5 \%$ & +0.0028 \\
\hline チャンネル幅 $+0.5 \%$ & +0.010 \\
\hline チャンネル幅 $-0.5 \%$ & -0.010 \\
\hline
\end{tabular}

表 1 に, 図 6 の $V_{\text {СHO }}$ を基準とした各場合のチャン ネル電位の変化, すなわち固定パターン雑音を示す. 表 1 から, チャンネル幅が変動すると大きな固定パ夕 ーン雑音が発生することがわかる，表 1 において，蓄 積領域濃度を増加すると, 負方向に固定パターン雑音 が発生するのは，これによってチャンネル電位が引き 下げられるためである。 また, チャンネル濃度やチャ ンネル幅の増加によって正方向に固定パターン雑音が 発生するのは, これらによってチャンネル電位が高く なるためである. 表 1 より, 固定パターン雑音がチャ ンネル濃度の変動に基づく場合でも, 全ランダム雑音 より約 85 倍大きいことがわかる，これらの值が大き めの見積りであるとしても, 固定パターン雑音の除去 はどうしても必要である.

ここで，スミアについて考察する．スミアは蓄積状 態にあるセルで入射光によって発生した電子が垂直信 号線に流れ出してくることによって発生する。すなわ ち, スミアはこれらの電子が読出し状態にあるセルの ドレインに流れ込む時チャンネル電位を変化させるた めに起こる.しかし, スミア量はこのように流れ出し てくる電荷量とチャンネルの電子排出能力に関係する ため, 定量化することは困難である。なお, チャンネ ルを $n$ 型にしたのは, 電子の排出能力を高めるため である。

\section{7. 検討}

この節では, 最初に埋込制御電極からの駆動速度, リセット電圧の減少法などについて検討し, ついで素 子全体の駆動法を提案し, 最後に固定パターン雑音の 除去法について述べる.

\section{1 制御電極からの駆動速度}

3 節で述べたような方法で素子を駆動すると, 水平 ブランキング期間は $0.83 \mu \mathrm{S}$ になる.この間に, 読出 し, リセットを行い蓄積モードに戻す必要がある。し たがって, 駆動パルスの立上り・立下り時間は約 200 ns 以下でなければならない.

いま, 制御電極から駆動される容量を計算するため
に, 図 6 の $\alpha=1.5 \mu \mathrm{m}$ の状態を考える.この時, 制 御電極から光透過性電極までの容量はセル当たり約 $4 \times 10^{-15} \mathrm{~F}$ になる. したがって, 1 水平ライン当たり の容量は $4 \times 10^{-12} \mathrm{~F}$ である. 制御電極からソースお よびドレインへの容量は正確には見積れないが, セル 容量と大体同じになる。したがって, 駆動すべき容量 は約 $8 \times 10^{-12} \mathrm{~F}$ である。一方, 制御電極の厚さを 1 $\mu \mathrm{m}$, 濃度が $1 \times 10^{20} / \mathrm{cm}^{3}$ の時の正孔の移動度を 60 $\mathrm{cm}^{2} / \mathrm{V} \cdot \mathrm{s}^{8)}$ とすると, 水平ライン当たりの抵抗は 1.6 $\times 10^{4} \Omega$ となる. したがって，集中定数的に考えると， 駆動パルスの立上り・立下りの時定数は約 $130 \mathrm{~ns}$ とな る.したがって, 埋込制御電極からの駆動は可能であ る.しかし, 制御電極がソースおよびドレインと接す る部分では, これらの濃度を低くして容量を小さくす るなどの土夫は必要である。また，このようにすると 蓄積領域とソースおよびドレインの間の容量も減少す る.

次に光透過性電極の厚さについて検討する. 光透過 性電極に課せられる条件は, そのセル当たりの抵抗を $R$ とすると

$$
R C_{c} \ll \Delta f
$$

である.（8)式において $C_{c}$ はセルの容量である. 光 透過性電極として, 濃度 $10^{18} / \mathrm{cm}^{3}$ の $n$ 型のポリシリ コンを用い, 移動度を $30 \mathrm{~cm}^{2} / \mathrm{V} \cdot \mathrm{s}$ とすると, 光透過 電極の厚さ $d$ は

$$
d \gg 1.7 \times 10^{-7} \mathrm{~cm}
$$

となる。したがって, 厚さは $50 \AA$ もあれば充分であ り, その光吸収は波長 $4500 \AA$ の時 $0.5 \%$ 以下である.

次に, リセット電圧の減少について検討しておく. 図 4 より明らかなように, 蓄積領域がちょうどリセッ 卜される時には, 酸化膜は $6.2 \mathrm{~V}$, 蓄積領域に 12.0 $\mathrm{V}$, チャンネル領域に $3.4 \mathrm{~V}$ 印加されている.リセッ 卜時に光透過性電極の電位をプラス方向にシフトし て, $\mathrm{Si}_{-}-\mathrm{SiO}_{2}$ 界面の電位を $0 \mathrm{~V}$ 以上にすれば, ソース およびドレインから界面に電子が注入され(ソースお よびドレインの電位はリセット時には $0 \mathrm{~V}$ とする)そ の電位は $0 \mathrm{~V}$ に固定される。したがって, リセット 電圧を酸化膜に印加されていた電圧だけ低くすること ができる。また 4 節で述べたように, 最大信号蓄積量 は充分であるので, 蓄積領域の幅を $2 / 3$ 程度に減少さ せてもよい。このようにすると蓄積領域に印加される 電圧は $(2 / 3)^{2}$ に減少する。したがって, この時りセ ットに必要な $\mathrm{Si}_{-}-\mathrm{SiO}_{2}$ 界面から制御電極までの電位差 は $8.5 \mathrm{~V}$ と小さくる。なお,このようなリセット 法を採用した時には, 蓄積時の制御電極電位の最適化 が必要である。 




図 11 駆動回路の一例

An example of driving circuit.

\section{2 素子の駆動法の一例}

図 11 は提案した素子の駆動法の一例である。セル のドレインはすべて共通で基板から取られている。ま た，セルのソースを結合した垂直信号線は，水平シフ トレジスタで順次オンされるスイッチと単一の抵抗を 通して $V_{s s}$ に達している。 また制御電極には, 制御パ ルス $\phi_{V 1}, \phi_{V 2}, \cdots$ 一゙ちえられている。こうによっ て水平ライン上のセルは同時にリセット, 蓄積, 信号 読出しをくり返しており, 水平ブランキング期間に蓄 積 読出し $\rightarrow$ リット $\rightarrow$ 蓄積の順でモードを変化させ て読出しを行うとする.

いま, 上から 2 番目の水平列が $\phi_{V 2}$ によって読出し モードにあり, 他の水平列は蓄積モードにあるとす る。また， $V_{S S}$ には前述したように $V_{O X}$ と $V_{C H}$ の間 の電位が与えられ， $V_{D D} に は 0 \mathrm{~V}$ の電位が与えられ ているとする. この時, 2 番目の水平列はすべてオン であり, 他の列はすべてオフである.いま, 水平レジ スタによってスイッチを切換えれば， 2 番目の水平列 のセルのチャネル電位によって決まる映像出力が順次 得られる. 次に $\phi_{V 2}$ をいったんりセット電位にしてか ら蓄積モードに戻せば，この水平ラインの撮像動作が 完了する. 同様な動作を順次他のラインに対して行え ば， 1 画面の撮像を行うことができる.しかし，この 映像出力に対して, 一定值を基準として DCレベルを 作れば，固定パターン雑音は避けられない。

\section{3 固定パターン雑音の除去法}

従来の素子において, 固定パターン雑音の除去はリ セットの前後のチャンネル電位の差をとることによっ て行われている4).すなわち, リセットの前のチャン ネル電位には信号とセル特性のばらつきの情報が含ま
れ, リセット後のチャンネル電位にはセル特性のばら つきの情報のみが含まれるので, これらの差をとるこ とによって固定パターン雑音の除去ができる．この原 理を提案した素子に適用すれば固定パターン雑音の除 去ができる．またこの時スミアの低減もできる，その 方法は 2 つ考えられる.

第 1 の方法は図 5 において, ソース電位を $V_{M A X}$ と $V_{\text {oxo }}$ の間に設定し, $\mathrm{Si}_{-} \mathrm{SiO}_{2}$ 界面の電位をりセットの 前後において検知する方法である。7.1節でこの方法 をとらなかったのは, ソース電位の設定值が負方向に かなりずれるため 1 次元解析の有効性を懸念したため である.

第 2 の方法は, 図 5 において, 酸化膜を厚くすると 同時にチャンネル濃度を増すことによって， $V_{O X}<$

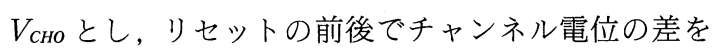
とる方法である。これらの方法が実現できるか否か は, さらに詳細な解析が必要である。

本報告の主旨は, 新しい構造の撮像素子を提案し, それが高い光電変換効率で動作し, 充分な信号電荷量 と高い変換係数を持つことを示すことにあるので, 固 定パターン雑音の除去については可能性を示すだけに とどめたい.

\section{8. むす び}

従来の増幅型撮像素子は, 受光面上に駆動用の電極 を持ち, その光吸収が光電変換効率の低下の原因にな っていた．本論文では, この欠点を解決するため, 次 の 2 点が新しい高感度撮像素子を提案した.

（1）セル分離領域上にハニカム状に抵抗の低い電 極を形成し, それから延びる光透過性電極でセ ルの受光面を覆った.

（2）基板中にセルのモード制御用の電極を埋込ん だ。

この構造では, 電極による光の吸収は無視できるの で, 高い光電変換感度が得られる.また, 制御電極の 電位を変化させることによって, リセット, 蓄積, 信 号読出しなどのモード制御が可能であることを示し た。

さらに, 提案した素子は, 残像やブルーミングが起 こらず，スミアの少ない光電変換素子として期待でき ることを示した。この構造を $1000 \times 1000$ セル $/ \mathrm{cm}^{2}$ の 素子に適用した場合, 光電変換感度は約 $2.9 \times 10^{9}$ hole $\cdot \mathrm{cm}^{2} / \mathrm{cell} \cdot \mathrm{W}$, 最大信号正孔数は約 $2.2 \times 10^{5}$ hole/cell, 信号正孔から信号電圧への変換係数は約 $5.7 \times 10^{-6} \mathrm{~V} /$ hole であった.これらの值は充分大き い. しかし, 暗電流のショット雑音や固定パターン雑 
音の除去が今後の課題として残されている.

雑音の評価法についてご教示いただいた東洋大学 菅野教授，信号の検出法について多くの検討をしてい ただいた当社研究開発グループ 栗山部長に深謝致し ます。

\section{〔参考 文 献]}

1) K. Matsumoto, T. Nakamura, A. Yusa, and S. Nagai : "A New MOS Phototransistor Operating in a Nondestructive Readout Mode", Jpn. J. Appl. Phys., 24, 4, pp. L 323-L 325 (1985)

2）森, 中村, 緒方, 大石, 大田, 松本, 酒井, 日向：“31 万画 素 CMD イメージャ”, 1989 テレビ全大, 2-11, pp. 33-34

3) J. Hynecek: "A New Device Architecture Suitable for High-Performance Image Sensors", IEEE. Trans. Electron Devices, 35, 5, pp. 646-652(1988)

4) J. Hyncek: BCMD-An Improved Photocite Structure for High Density Image Sensors", IEEE Trans. Electron Devices, 38, 5, pp. 1011-1020(1991)

5) C. T. Sah: "Physics of Semiconductor Devices", WileyInterscience, New York, p. 357(1969)

6) A. van der Ziel : "Thermal Noise in Field-Effect Transistors", Proceendings of the IRE, 50, 8, pp. 1808-1812(1962)

7) C. T. Sah: "Theory of Low Frequency Generation Noise in Junction Field Transistors", Proc. IEEE, 52, 7, pp. 759 $-814(1964)$

8) J. C. Irvin: "Rsistivity of Bulk Silicon and of Diffused Layers in Silicon", Bell System Tech. Jour., 41, 3, pp. 387 $-410(1961)$

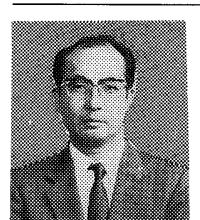

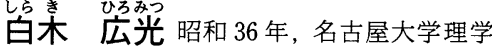
部物理学科卒業. 同年, 白本電気 (株) に入 社. 撮像管, $\mathrm{Si}$-ビジコン, $\mathrm{CCD}$ および集積 回路の研究に従事. マイクロエレクトロニク ス研究所センサ研究部長, 同所長を務める。 現在, 主席研究員. 工学博士. 正会員. 